\title{
Assessing the Suitability of Agro-Waste from Oil Palm Empty Fruit Bunches as Quality Eco-Composite Boards
}

\author{
Razak Wahab ${ }^{1}$, Mohd Sukhairi Mat Rasat ${ }^{2}$, Hashim W. Samsi ${ }^{3}$, Mohd Tamizi Mustafa ${ }^{3} \&$ Siti Marlia Mohd Don $^{2}$ \\ ${ }^{1}$ University College of Technology Sarawak, Sibu, Sarawak, Malaysia \\ ${ }^{2}$ Universiti Malaysia Kelantan (UMK), Jeli Campus, Jeli, Kelantan, Malaysia \\ ${ }^{3}$ Forest Research Institute Malaysia (FRIM), Kuala Lumpur, Malaysia \\ Correspondence: Razak Wahab, University College of Technology Sarawak, 96000 Sibu, Sarawak, Malaysia. Tel: \\ 6019-862-8787. E-mail: drrazakw5181@ucts.edu.my
}

Received: May 29, 2017

doi:10.5539/jas.v9n8p237
Accepted: June 26, $2017 \quad$ Online Published: July 15, 2017

URL: https://doi.org/10.5539/jas.v9n8p237

\begin{abstract}
The properties of eco-composite boards from agro-waste of oil palm empty fruit bunches were studied. The oil palm empty fruit bunches (EFB) obtained from a private oil palm plantation. By using fibre cutter and particle crusher, these EFB refined. Hardeners and wax added at $1 \%$ and $3 \%$ during the mixing process. Boards with densities of 500,600 and $700 \mathrm{~kg} / \mathrm{m}^{3}$ produced using resin urea formaldehyde as the bonding agent at 10,12 and $14 \%$. The boards conditioned in a conditioning chamber set at $20 \pm 2{ }^{\circ} \mathrm{C}$ and $65 \%$ relative humidity before undergoing subsequent testing. The EN Standards specifications applied in the preparation of test samples and testing. Results showed the highest modulus of rupture (MOR) and modulus of elasticity (MOE) achieved in this study were $22.91 \mathrm{~N} / \mathrm{mm}^{2}$ and $2059.56 \mathrm{~N} / \mathrm{mm}^{2}$. The internal bonding was found to be at $0.98 \mathrm{~N} / \mathrm{mm}^{2}$, and 467.47 $\mathrm{N} / \mathrm{mm}^{2}$ and $512.37 \mathrm{~N} / \mathrm{mm}^{2}$ respectively for the edge and face screw withdrawal. Boards with $700 \mathrm{~kg} / \mathrm{m}^{3}$ density and $14 \%$ resin content met the requirement of standard specifications. Scanning electron microscopy machine used to study the resin-fibre bonding property. Resin and fibre in the board inspected carefully, and voids appeared at the cross-section of the board with density $500 \mathrm{~kg} / \mathrm{m}^{3}$ at $10 \%$ resin suggesting moisture penetrated into the board via the open spaces and weakened the linkages existed, thus cause the board to have low properties. The thermogravimetric analysis indicates maximum rate of decomposition for the EFB boards occurred at $380.83{ }^{\circ} \mathrm{C}$. This study shows that the board's density and resin content applied influence on the board's overall properties with boards produced at $700 \mathrm{~kg} / \mathrm{m}^{3}$ density with $14 \%$ resin content showed excellent overall properties with good dimensional stability.
\end{abstract}

Keywords: empty fruit bunch, eco-composite boards, boards properties, scanning electron microscope, thermogravimetric analysis

\section{Introduction}

The timber industry has started slowly to turn to wood composite as an alternative to the use of natural timber. The demands for natural timber have increased due to the shortage of the wood supply (Wahab et al., 2008, 2016; Rasat et al., 2013a; Rowell, 2012). Oil palm is a valuable plantation and by far the largest crop in Malaysia. The oil palm trees become unproductive economically after reaching 25-30 years and need replanting. An enormous amount of oil palm biomass becomes available during this period. This biomass usually left to rot in the fields. This readily available renewable resource could be used as a raw material for wood-based industry (Rasat et al., 2013b, 2013c, 2013e). Several studies have been conducted to determine the suitable of using the lignocellulose material from oil palm trunks to replace wood in wood-based panel industry. Apart from the abundance of oil palm stems, EFB is another type of the oil palm biomass that can be utilized. EFB is amounting to 12.4 million tons per year (fresh weight) and regularly discharged from palm oil refineries (Khalil et al., 2007). It is a lignocellulosic material that has potential as the natural fibre resource. The moisture content of fresh EFB is very high, about over $60 \%$ on a wet EFB basis. EFB is a poor material fuel and presents a considerable emission problem during burning. Palm oil mills typically use the shell and drier part of the fibre product rather than EFB, to fuel their boilers (Abdullah \& Bridgwater, 2006). EFB are available in abundance in Malaysia, converting them into composite boards can be a way to resolve the scarcity of wood sources in the tropical region of the world where the plants grow. 
The present study focuses on assessing the suitability of using agro-waste from oil palm empty fruit bunches as quality eco-composite boards. The information obtained in the study can help the wood industry in enhancing the utilization of this empty fruit bunches as an alternative to timber.

\section{Materials and Methods}

The oil palm EFB samples were obtained from a private plantation located in Selangor. The materials refined into smaller size using the mechanical cutter and crusher. A four-tier sieve shaker used to screen and remove the oversize, fines and impurities. The particles were then passed through $2.0 \mathrm{~mm}$ sieve size and retained at $1.5 \mathrm{~mm}$ sieve size. The particles were oven-dried at $103 \pm 2{ }^{\circ} \mathrm{C}$ for $24 \mathrm{hrs}$. The mass of the particles was measured to obtain targeted densities of 500, 600 and $700 \mathrm{~kg} \mathrm{~m}^{-3}$. They mixed with the urea-formaldehyde (UF) resin in a mixing drum. Three (3) levels of resin content were applied to the boards' production at 10,12 and $14 \%$. The mixed particles were hand-felted into a wooden frame $340 \times 340 \mathrm{~mm}$ size of a caul plate. The formed mat was pre-pressed by using the cold press machine. The forming frame removed leaving the mat on the caul plate. The mat was hot-pressed under Taihei hot-press machine at temperature $165^{\circ} \mathrm{C}$ to the duration of 6 minutes. Four metal bars of $12 \mathrm{~mm}$ thickness were used in the hot-pressing process. The boards produced were then cooled and cut into standard testing size. The testing samples stored in a conditioning chamber conditioned at $20 \pm 2{ }^{\circ} \mathrm{C}$ and $65 \%$ relative humidity until reaching their constant weight, before the testing procedure. Boards at densities of 500,600 and $700 \mathrm{~kg} \mathrm{~m}^{-3}$ and UF resin application at 10, 12 and 14\% were produced in laboratory scale. All boards were provided by European Standard (EN Standard).

\subsection{Physical Properties}

The physical studies conducted were the density, moisture content, water absorption, and thickness swelling tests of 2 and 24 hours elapsed of the EFB composite boards. Physical studies were carried out by the standard of EN 322 (European Standard, 1993a), EN 323 (European Standard, 1993b) and EN 317 (European Standard, 1993c).

\subsection{Strength Properties}

The strength measurement carried out including the static bending test including modulus of rupture (MOR) and modulus of elasticity (MOE), internal bonding test and screw withdrawal test (edge and face). All the tests were conducted by using the universal testing machine in according to the standard of EN 310 (European Standard, 1993d) and EN 325 (European Standard, 2012). Screw hold strength of the OPEFB composite boards was tested according to the standard of BS 5669 (British Standard, 1989).

\subsection{Scanning Electron Microscopy}

The microscopy study was conducted to examine the structure of the boards on their physical, strength and thermal properties. The boards were viewed at the cross-cut to investigate the interaction between resin UF and EFB particles. The study was conducted using the FEI Quanta 200 SEM located at the FRIM Pulp and Paper Laboratory, Kepong. Samples of the boards with a dimension of $1 \times 1 \times 1 \mathrm{~cm}$ were used. The SEM equipment was connected to a computer for image storage and processing.

\subsection{Thermogravimetric Analysis}

Thermogravimetric analysis (TGA) was used to measure the thermal stability of the boards. The weight change with temperature was measured and used to infer the moments of change during the heating. Temperature occurred when the boards started to degrade taken as an indicator of the stability of the material (Soom et al., 2006). Thermal analysis was carried out with a digital TA Instrument SDT-Q600 thermogravimetric analyzer. Samples $(5.5 \pm 0.2 \mathrm{mg})$ placed in alumina crucibles. TGA performed under $100 \mathrm{ml} \mathrm{min}^{-1}$ nitrogen with a heating rate of $10^{\circ} \mathrm{C} \mathrm{min}^{-1}$.

\section{Results and Discussion}

\subsection{Physical Properties}

The physical properties comprise of the density, moisture content, thickness swelling, and water absorption at 2 and 24 hours elapsed time of the EFB composite boards manufactured. Table 1 shows the density of the EFB composite boards. Boards' at density $500 \mathrm{~kg} / \mathrm{m}^{3}$ with $10 \%$ resin content level had an average density of 506.29 $\mathrm{k} / \mathrm{gm}^{3}, 12 \%$ resin content with $506.9 \mathrm{~kg} / \mathrm{m}^{3}$ and $14 \%$ resin content at $517.6 \mathrm{~kg} / \mathrm{m}^{3}$. Board $600 \mathrm{~kg} / \mathrm{m}^{3}$ with $10 \%$ resin content level had an average density of $598.65 \mathrm{~kg} / \mathrm{m}^{3}, 12 \%$ resin content with $608.9 \mathrm{~kg} / \mathrm{m}^{3}$ and $14 \%$ resin content at $620.05 \mathrm{k} / \mathrm{gm}^{3}$. Average density of the board $700 \mathrm{~kg} / \mathrm{m}^{3}$ is $704.03 \mathrm{~kg} / \mathrm{m}^{3}$ with $10 \%$ resin, $714.72 \mathrm{~kg} / \mathrm{m}^{3}$ with $12 \%$ resin, and $723.89 \mathrm{k} / \mathrm{gm}^{3}$ with $14 \%$ resin. The boards at density $500 \mathrm{~kg} / \mathrm{m}^{3}$ possess MC value of $6.89 \%$ at $10 \%$ resin, $7.15 \%$ at $12 \%$ resin, and $8.48 \%$ at $14 \%$ resin. Boards at $600 \mathrm{~kg} / \mathrm{m}^{3}$ have $\mathrm{MC}$ of $6.04 \%$ at $10 \%$ resin, 
$6.83 \%$ at $12 \%$ resin, and $6.48 \%$ at $14 \%$ resin. The board's density of 700 possesses MC at $6.64 \%$ with $10 \%$ resin, $6.72 \%$ with $12 \%$ resin, and $7.12 \%$ with $14 \%$ resin.

Thickness swelling properties of the EFB composite boards manufactured were obtained from the thickness swelling analysis. Time elapsed of 2 and 24 hours thickness swelling analysis was carried out, and percentage of increment of thickness was then calculated. Boards with densities of 500,600 and $700 \mathrm{~kg} / \mathrm{m}^{3}$ possess a particular trend of 2 and 24 hours thickness swelling where the swelling decreased as the amount of resin applied increased The boards at $500 \mathrm{~kg} / \mathrm{m}^{3}$ at resin content $10 \%$ had the highest rate of thickness swelling for 2 hours' time elapsed at $35.1 \%$. The lowest value of 2 hours thickness swelling was given by the board $700 \mathrm{~kg} / \mathrm{m}^{3}$ with resin content $14 \%$ at $16.34 \%$. The highest value for 24 hours, thickness swelling was attained by the board $500 \mathrm{~kg} / \mathrm{m}^{3} \mathrm{with}$ resin content $10 \%$ at $41.11 \%$. The boards at $700 \mathrm{~kg} / \mathrm{m}^{3}$ with resin content $14 \%$ had the lowest 24 hours thickness swelling at $12.99 \%$.

Table 1. Density of EFB composite boards and values for thickness swelling at different density moreover, resin contents for 2 and 24 hours time elapsed

\begin{tabular}{llllll}
\hline $\begin{array}{l}\text { Board density } \\
\left(\mathrm{kg} / \mathrm{m}^{3}\right)\end{array}$ & $\begin{array}{l}\text { Resin content } \\
(\%)\end{array}$ & $\begin{array}{l}\text { Moisture content } \\
(\%)\end{array}$ & $\begin{array}{l}\text { Density } \\
\left(\mathrm{kg} / \mathrm{m}^{3}\right)\end{array}$ & $2 \mathrm{~h}$ & $24 \mathrm{~h}$ \\
\hline 500 & 10 & $6.89(0.42)$ & $506.29(31.27)$ & $35.10(2.75)$ & $41.11(2.86)$ \\
& 12 & $7.15(0.43)$ & $506.90(25.54)$ & $26.44(3.42)$ & $38.25(2.61)$ \\
& 14 & $8.48(0.26)$ & $517.60(14.25)$ & $24.90(0.63)$ & $26.69(1.18)$ \\
\hline 600 & 10 & $6.04(0.72)$ & $598.65(14.43)$ & $24.04(2.56)$ & $25.46(1.50)$ \\
& 12 & $6.83(0.81)$ & $608.90(27.31)$ & $23.01(0.68)$ & $24.41(1.84)$ \\
& 14 & $6.48(1.16)$ & $620.05(25.19)$ & $20.90(1.73)$ & $21.41(2.78)$ \\
700 & 10 & $6.64(0.29)$ & $704.03(31.91)$ & $19.18(0.43)$ & $21.37(0.54)$ \\
& 12 & $6.72(0.46)$ & $714.72(7.21)$ & $17.46(1.20)$ & $16.88(0.43)$ \\
& 14 & $7.12(0.30)$ & $723.89(17.47)$ & $16.34(0.19)$ & $12.99(2.50)$ \\
\hline
\end{tabular}

Note. Standard deviations are shown in bracket.

Some chemical components in the resin applied capable of cross-linking with the hydroxyl group of the fibre reducing the hygroscopicity of the boards. Hygroscopic expansion can be affected by various factors of the resin, polymerization rates, cross-linking, and pore-size of the polymer network, bond strength, interaction between polymer and water, the filler and the resin-filler interface (Wei et al., 2011). According to the theory of voids over the volume of the board, the greater existence of the void that can mostly found in low-density boards than high-density boards may provide spaces that increase water absorption (Loh et al., 2010). In the low-density board, the highly porous structure allows penetration of water into the board and increases the water uptake resulting in high water absorption, causes the board to swell and gives rise in thickness swelling (Wong et al., 1999).

Table 2. Water absorption of EFB boards at different density and resin contents for 2 and 24 hrs time elapsed

\begin{tabular}{llll}
\hline \multirow{2}{*}{ Board density $\left(\mathrm{kg} / \mathrm{m}^{3}\right)$} & Resin content $(\%)$ & \multicolumn{2}{c}{ Water absorption (\%) } \\
\cline { 3 - 4 } & 10 & $139.02(5.71)$ & $24 \mathrm{hrs}$ \\
\hline 500 & 12 & $119.20(3.06)$ & $140.81(3.93)$ \\
& 14 & $113.26(7.59)$ & $138.29(2.55)$ \\
\hline 600 & 10 & $92.50(7.38)$ & $127.48(6.16)$ \\
& 12 & $82.78(5.95)$ & $108.58(2.05)$ \\
700 & 14 & $79.84(5.23)$ & $96.95(3.45)$ \\
& 10 & $64.24(3.32)$ & $91.22(2.56)$ \\
& 12 & $44.27(3.09)$ & $69.12(5.24)$ \\
\hline
\end{tabular}

Note. Standard deviations are shown in bracket. 
Water absorption property of the EFB composite boards manufactured was obtained from water absorption analysis. Time elapsed of 2 and 24 hours water absorption studies were carried out. The water absorption of EFB composite boards at different density, and resin content is shown Table 2 . The boards of 500,600 and $700 \mathrm{~kg} / \mathrm{m}^{3}$ densities showed the same trend of 2 and 24-hour water abortion where the rate of the board absorbed water decreases as the amount of resin applied increases. Boards at density $500 \mathrm{~kg} / \mathrm{m}^{3}$ with resin content $10 \%$ had the highest rate of 2-hour water absorption at $139.02 \%$ while the lowest at $40.71 \%$ given by the $700 \mathrm{~kg} / \mathrm{m}^{3}$ board density of resin content $14 \%$. The highest rate of 24 hours water absorption was attained by the board at 500 $\mathrm{kg} / \mathrm{m}^{3}$ density with resin content $10 \%$ at $206.77 \%$. The lowest value at 24 hours water intake at $59.62 \%$ obtained by the board $700 \mathrm{~kg} / \mathrm{m}^{3}$ with $14 \%$ resin. The increase in the board density resulted in a better thickness swelling performance and decreased water absorption of the boards (Rasat et al., 2013d; Guler \& Büyüksar1, 2011). The boards with high density absorbed more water than those with low density. The adhesion strength of the board decreases when the dwell inside the water increases, resulting in the increase in the thickness of the boards. The increment in the adhesion ratio resulted in low thickness swelling and water absorption for the boards. The swelled boards remained deficient even after the increases in the boards' density and adhesive (Wahab et al., 2016a; Garay et al., 2009). Increases in the density of the boards significantly improved the strength and water resistance (Zheng et al., 2005). The high-density boards possess large contact surface area between particles, making the adhesive function more efficiently compared to the lower density particle board (Zheng et al., 2005). The boards with higher density have less void volume, resulting in better water resistance. Although boards with high density normally correspond to high quality, it also means higher cost and weight of the finished composite board. Khalid et al. (2015) made a similar observation in their studies in the evaluation of layering effects and adhesive rates on laminated compressed composite panels from oil palm.

\subsection{Strength Properties}

The procedure of testing executed as outlined in standards of EN 310 (European Standard, 1993d) and EN 325 (European Standard, 2012). The results of the MOR obtained compared with rubber wood and analyzed by using the universal testing machine, where the sample of EFB board $(290 \times 50 \times 12 \mathrm{~mm})$ placed flat on the supports as the load applied. Results of MOR obtained compared with rubber wood. Table 3 presents MOR of the EFB composite board at density 500,600 and $700 \mathrm{~kg} / \mathrm{m}^{3}$. It noted that resistance to rupture increase with the increasing of board density and resin content. Board $700 \mathrm{~kg} / \mathrm{m}^{3}$ with $14 \%$ resin content had the highest MOR at $22.91 \mathrm{~N} / \mathrm{mm}^{2}$ followed by the board made with a resin content of $12 \%$ at $18.97 \mathrm{~N} / \mathrm{mm}^{2}$ resin with the same density. Lower MOR attained by the boards with density $500 \mathrm{~kg} / \mathrm{m}^{3}$ with $10 \%$ resin content at $6.07 \mathrm{~N} / \mathrm{mm}^{2}$ followed by $12 \%$ at $6.37 \mathrm{~N} / \mathrm{mm}^{2}$ ) and $14 \%$ at $6.75 \mathrm{~N} / \mathrm{mm}^{2}$ resin content. The boards of $600 \mathrm{~kg} / \mathrm{m}^{3}$ give an increasing trend from $10 \%$ at $10.2 \mathrm{~N} / \mathrm{mm}^{2}$ to $12 \%$ at $10.26 \mathrm{~N} / \mathrm{mm}^{2}$ and $14 \%$ at $12.77 \mathrm{~N} / \mathrm{mm}^{2}$ resin content. The EFB boards at density $700 \mathrm{~kg} / \mathrm{m}^{3}$ with 12 and $14 \%$ resin contents passed the minimum requirement for MOR at $14 \mathrm{~N} / \mathrm{mm}^{2}$ for general use's type according to the standard of EN 312-3 (European Standard, 1996). Compared with a convenient board made from rubber wood (Paridah et al., 2010), the MOR value of EFB composite board $700 \mathrm{~kg} / \mathrm{m}^{3}$ with $14 \%$ had a quite identical property at 22.91 to $22.8 \mathrm{~N} / \mathrm{mm}^{2}$.

Table 3. MOR and MOE of EFB boards at different density and resin content

\begin{tabular}{llll}
\hline Board density $\left(\mathrm{kg} / \mathrm{m}^{3}\right)$ & Resin content $(\%)$ & MOR $\left(\mathrm{N} / \mathrm{mm}^{2}\right)$ & MOE $\left(\mathrm{N} / \mathrm{mm}^{2}\right)$ \\
\hline 500 & 10 & $6.07(1.54)$ & $385.64(108.02)$ \\
& 12 & $6.37(0.88)$ & $419.43(88.55)$ \\
& 14 & $6.75(1.47)$ & $447.44(134.29)$ \\
\hline 600 & 10 & $10.20(0.79)$ & $673.82(55.64)$ \\
& 12 & $10.26(3.07)$ & $773.37(156.73)$ \\
700 & 14 & $12.77(3.37)$ & $1006.78(231.94)$ \\
& 10 & $11.03(3.33)$ & $1063.43(348.71)$ \\
& 12 & $18.97(3.09)$ & $1683.93(255.10)$ \\
EN 312-3 & 14 & $22.91(3.81)$ & $2059.56(285.01)$ \\
Rubber wood & & 14.0 & 1800 \\
\hline
\end{tabular}

Note. * Paridah et al. (2010), and the standard deviations are shown in bracket. 
MOE is related to the stiffness of the board, and the higher the MOE, the greater the stiffness. The boards tend to be brittle when the MOE is high and tends to be ductile or flexible when the value is small (Wahab et al., 2016b; 2013; Rasat et al., 2011; Yang et al., 2003). MOE analysis conducted using the universal testing machine. The MOE values obtained as the constant load applied to the testing EFB composite boards. The values MOE compared with rubber wood. MOE of EFB boards is presented in Table 3. The highest value of MOE attained by the board at density $700 \mathrm{~kg} / \mathrm{m}^{3}$ with $14 \%$ resin content at $2059.56 \mathrm{~N} / \mathrm{mm}^{2}$ followed by $12 \%$ at $1683.93 \mathrm{~N} / \mathrm{mm}^{2}$ and $10 \%$ at $1063.43 \mathrm{~N} / \mathrm{mm}^{2}$ resin of the same density of the board. Boards at density $500 \mathrm{~kg} / \mathrm{m}^{3}$ with $10 \%$ at $385.64 \mathrm{~N} / \mathrm{mm}^{2}$ resin has low MOE followed by $12 \%$ at $419.43 \mathrm{~N} / \mathrm{mm}^{2}$ and $14 \%$ at $447.44 \mathrm{~N} / \mathrm{mm}^{2}$ resin of the same density. MOE value of the board $600 \mathrm{~kg} / \mathrm{m}^{3}$ is an increase from $10 \%$ at $673.82 \mathrm{~N} / \mathrm{mm}^{2}$ to $12 \%$ at 773.37 $\mathrm{N} / \mathrm{mm}^{2}$ and $14 \%$ at $1006.78 \mathrm{~N} / \mathrm{mm}^{2}$ resin content. The EFB boards at density $700 \mathrm{~kg} / \mathrm{m}^{3}$ with $14 \%$ resin content not only met the minimum requirement for MOE at $1800 \mathrm{~N} / \mathrm{mm}^{2}$ for general use's type of board according to the standard of EN 312-3 but exceeded the required values. The maximum MOE value of the EFB composite boards manufactured in this study is at $2059.56 \mathrm{~N} / \mathrm{mm}^{2}$. This value is slightly lower than the MOE of rubber wood at $2381 \mathrm{~N} / \mathrm{mm}^{2}$.

Internal Bonding (IB) test conducted to determine the interfacial bonding strength between fibres in the boards. The test underwent by using the universal testing machine, where the top and bottom of EFB composite boards glued on metal blocks slotted into the testing assembly. It was evident from Table 4 that the EFB composite boards $700 \mathrm{~kg} / \mathrm{m}^{3}$ with $14 \%$ resin content give the highest IB value at $0.98 \mathrm{~N} / \mathrm{mm}^{2}$ followed by $12 \%$ at 0.77 $\mathrm{N} / \mathrm{mm}^{2}$ resin content of the same board density. The lowest value of IB was reported by the boards at $500 \mathrm{k} / \mathrm{gm}^{3}$ with $10 \%$ at $0.18 \mathrm{~N} / \mathrm{mm}^{2}$ followed by $12 \%$ at $0.19 \mathrm{~N} / \mathrm{mm}^{2}$ and $14 \%$ at $0.23 \mathrm{~N} / \mathrm{mm}^{2}$ resin content of the same board density. IB value of the panel $600 \mathrm{~kg} / \mathrm{m}^{3}$ increase from $10 \%$ at $0.28 \mathrm{~N} / \mathrm{mm}^{2}$ to $12 \%$ at $0.31 \mathrm{~N} / \mathrm{mm}^{2}$ and $14 \%$ at $0.36 \mathrm{~N} / \mathrm{mm}^{2}$ resin content. EFB composite boards $700 \mathrm{~kg} / \mathrm{m}^{3}$ with 10,12 and $14 \%$ resin contents were passed the minimum required value of the general type of board at $0.4 \mathrm{~N} / \mathrm{mm}^{2}$. The IB values obtained from the EFB composite boards were slightly lower than of rubber wood at $1.3 \mathrm{~N} / \mathrm{mm}^{2}$. The boards with low density possess low IB due to the existence of more voids in it. Poor boards preparation will lead to most of the interparticle spaces remaining as voids. The voids directly caused inefficiency of the inter-fibre bonding (Ashori \& Nourbakhsh, 2008).

Table 4. Internal bonding of EFB boards at different density and resin content

\begin{tabular}{lllll}
\hline Board density $\left(\mathrm{kg} / \mathrm{m}^{3}\right)$ & Resin content $(\%)$ & Internal bonding $\left(\mathrm{N} / \mathrm{mm}^{2}\right)$ & $\mathrm{SWe}\left(\mathrm{N} / \mathrm{mm}^{2}\right)$ & $\mathrm{SWf}\left(\mathrm{N} / \mathrm{mm}^{2}\right)$ \\
\hline 500 & 10 & $0.18(0.04)$ & $168.18(23.56)$ & $193.42(29.58)$ \\
& 12 & $0.19(0.02)$ & $178.82(39.51)$ & $244.50(50.53)$ \\
\hline 600 & 14 & $0.23(0.03)$ & $189.93(20.05)$ & $268.38(48.04)$ \\
& 10 & $0.28(0.07)$ & $232.72(20.19)$ & $305.40(24.23)$ \\
700 & 12 & $0.31(0.08)$ & $239.08(25.01)$ & $314.60(34.51)$ \\
& 14 & $0.36(0.17)$ & $302.13(41.53)$ & $321.62(32.27)$ \\
\hline EN 312-3 & 10 & $0.54(0.06)$ & $412.27(38.10)$ & $459.72(42.45)$ \\
Rubber wood & 12 & $0.77(0.12)$ & $440.67(35.38)$ & $511.23(32.45)$ \\
\hline
\end{tabular}

Note. * Paridah et al. (2010), and the standard deviations are shown in bracket.

Platen temperature was found to influences the internal bonding results of the composite boards. Internal bonding of UF resin composite board significantly improved with the increase in the platen temperature. The Higher temperature of the platen promotes higher cross-linking and curing of the resin. During pressing process, the temperature at a board's core is the lowest compared to the surface. Corrected platen temperature has to be applied to ensure that the core reaches a sufficiently high temperature to allow the resin to cure. Application of wax can result in lower internal bonding. The differences in chemical bonding between UF resin and particles and the wax interferes with the UF resin when hydrogen bonds formed (Papadopoulos, 2007).

The edge screw withdrawal test conducted to evaluate the screw holding strength at the edge sections of the boards. A screw inserted upright into the holes at the edge side of the test sample and placed in a stirrup attached to the load. The edge screw withdrawal property obtained as the load applied to a pulling action. Table 4 showed 
the results of the edge screw withdrawal tests on EFB composite boards. The boards at density $700 \mathrm{k} / \mathrm{gm}^{3}$ with $14 \%$ resin gives the highest value at $467.47 \mathrm{~N} / \mathrm{mm}^{2}$, followed by $440.67 \mathrm{~N} / \mathrm{mm}^{2}$ with $12 \%$ and $412.27 \mathrm{~N} / \mathrm{mm}^{2}$ with $10 \%$ resin of the same density boards. The lowest value of edge screw withdrawal was given by the board at $500 \mathrm{~kg} / \mathrm{m}^{3}$ with $10 \%$ resin was $168.18 \mathrm{~N} / \mathrm{mm}^{2}$ content followed by $12 \%$ at $178.82 \mathrm{~N} / \mathrm{mm}^{2}$ and $14 \%$ resin at $189.93 \mathrm{~N} / \mathrm{mm}^{2}$ of the same boards' density. The edge screw withdrawal value for boards at $600 \mathrm{~kg} / \mathrm{m}^{3}$ increases from $10 \%$ at $232.72 \mathrm{~N} / \mathrm{mm}^{2}$ to $12 \%$ at $239.08 \mathrm{~N} / \mathrm{mm}^{2}$ and $14 \%$ resin at $302.13 \mathrm{~N} / \mathrm{mm}^{2}$. The EFB composite boards at $700 \mathrm{~kg} / \mathrm{m}^{3}$ with 10,12 and $14 \%$ resin met the minimum requirement for edge screw withdrawal according to BS 5669 (British Standard, 1989). They exceeded the $360 \mathrm{~N} / \mathrm{mm}^{2}$ value that used as the standard.

A screw inserted upright into the holes on the face side of the test boards and placed in a stirrup attached to the load. The test conducted to evaluate the screw holding strength on the face sections of the boards. The results of edge screw withdrawal property obtained as the load applied to a pulling action. Table 4 presents face screw withdrawal of the EFB composite boards manufactured. Boards of $700 \mathrm{~kg} / \mathrm{m}^{3}$ with $14 \%$ resin content gives the highest values in the screw withdrawal at $512.37 \mathrm{~N} / \mathrm{mm}^{2}$ followed by $12 \%$ at $511.23 \mathrm{~N} / \mathrm{mm}^{2}$ and $14 \%$ resin at $459.72 \mathrm{~N} / \mathrm{mm}^{2}$ of the same density boards. The lowest value was obtained by boards having a density of 500 $\mathrm{kg} / \mathrm{m}^{3}$ with $10 \%$ at $193.42 \mathrm{~N} / \mathrm{mm}^{2}$ resin content followed by $12 \%$ at $244.5 \mathrm{~N} / \mathrm{mm}^{2}$ and $14 \%$ resin at 268.38 $\mathrm{N} / \mathrm{mm}^{2}$ of the same density boards. Face screw withdrawal of the boards with $600 \mathrm{~kg} / \mathrm{m}^{3}$ increases from $10 \%$ resin at $305.4 \mathrm{~N} / \mathrm{mm}^{2}$ to $12 \%$ at $314.6 \mathrm{~N} / \mathrm{mm}^{2}$ and $14 \%$ resin at $321.62 \mathrm{~N} / \mathrm{mm}^{2}$. The higher particle loading was to strengthen the boards as well as increases their densities assists the boards to hold the screw better. The screw withdrawal resistance is highly associated with the board density and the particles' geometry (Wahab et al., 2008; 2016c; Wong et al., 1999).

\subsection{Microscopy Studies}

Samples for this study randomly selected from the EFB boards for observations of their structure especially the occurrence of the fibres compression, binder-fibre compatibility and void's occurrence. The boards sampled at a density of $500 \mathrm{~kg} / \mathrm{m}^{3}$ with UF resin content of $10 \%$ were taken for the micrographic studies as the boards have the lowest physical and strength properties). Figures 1 and 2 show the micrographs of a cross-section of EFB composite board with resin content level $10 \%$ at $100 \times$ and $500 \times$ magnification. Figure 1 showed the occurrences of fibres compression in the EFB composite boards. The compression of fibres occurred during the pressing stage at different applied pressure and temperatures. EFB fibres in the boards' profile were forced to shrink to a specified thickness resulting in the compressed structure of the fibres. This led to the reduction of lumen void spaces and thus, increase the density of the board produced (Moslemi, 1974). Figure 2 shows a good compatibility between EFB fibre and UF resin in the particle board manufactured. The fibres touch one to the others closely, and no UF resin observed clumped. This affects the result of the strength properties of the MOR and MOE properties of the board (Wai et al., 2011). As the load applied perpendicular to the EFB board surface, it creates compression stress on the top side on the board that transforms into tension stress at the bottom after exceeding the middle portion. The load stresses transferred from one particle to another particle, which, in this case, the EFB fibre's acts through a medium of the load transfer (Paridah et al., 2010). However, some voids do appear in the board's profile. The existence of voids in the EFB composite board profile reveals that there were empty spaces or gaps occurred at a particular area on the board, which might lead to the higher water absorption. The voids created more surfaces of EFB fibre to be exposed to the surrounding humidity (Wei et al., 2011). The void's occurrence can be reduced by using or mixing smaller sizes of particles in the board manufacturing (Marashdeh et al., 2011). Boards with the smoother surface will be able to produce, and the tiny particles will not go wasted. 


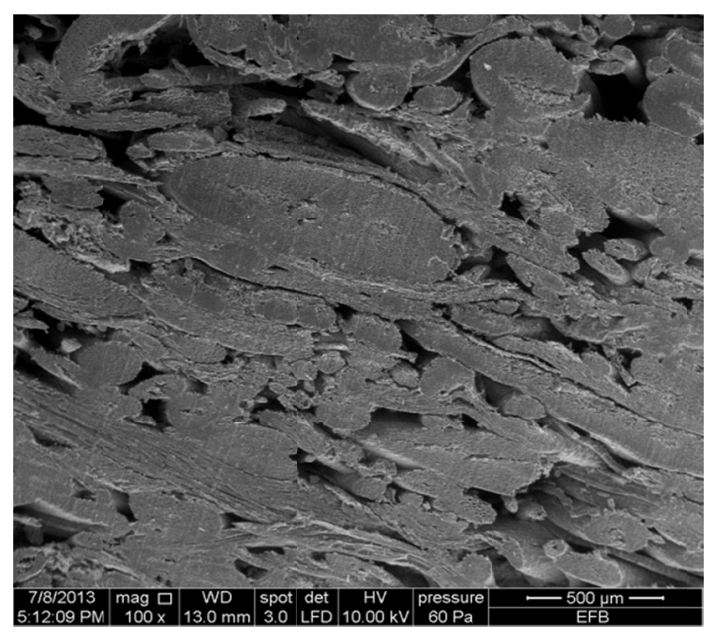

Figure 1. Micrographs of a cross section at density $500 \mathrm{k} / \mathrm{gm}^{3}$ EFB composite boards with resin $10 \%$ at $100 \times$ magnification

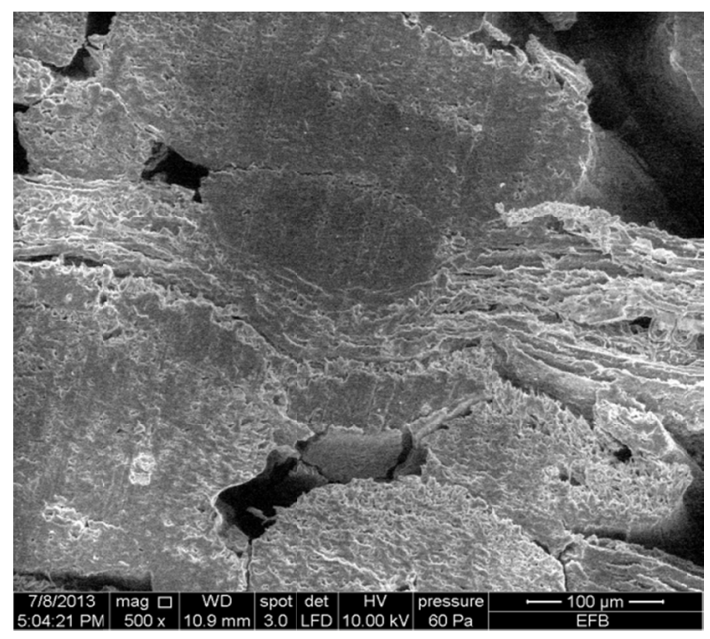

Figure 2. Micrographs of a cross section at density $500 \mathrm{k} / \mathrm{gm}^{3} \mathrm{EFB}$ composite boards with resin $10 \%$ at $500 \times$ magnification

\subsection{Thermal Characteristics}

The thermal characteristics of the EFB boards and UF resin samples were analyzed with a computerized TA Instruments SDT-Q600 TGA. The TGA performed on $100 \mathrm{mlmin}^{-1}$ nitrogen gases at a heating rate $10{ }^{\circ} \mathrm{C} / \mathrm{min}$. Figure 3 shows the TGA result for EFB composite boards. The decomposition in EFB composite boards began at $100.46{ }^{\circ} \mathrm{C}\left(1^{\text {st }}\right.$ peak $)$. It continued to the $2^{\text {nd }}$ peak at $204.81^{\circ} \mathrm{C}$ and completed at the $3^{\text {rd }}$ peak $\left(380.83{ }^{\circ} \mathrm{C}\right)$. Figure 4 shows the degradation of UF resin initiated at $99.93{ }^{\circ} \mathrm{C}\left(1^{\text {st }}\right.$ peak $)$, continued at $168.45{ }^{\circ} \mathrm{C}\left(2^{\text {nd }}\right.$ peak $)$ and completed at $389.26{ }^{\circ} \mathrm{C}\left(3^{\text {rd }}\right.$ peak). Table 5 represents TGA weight loss (\%) with temperature for UF resin boards. The loss of UF resin in weight was the highest at $3^{\text {rd }}$ peak at $58.48 \%$, followed by the $2^{\text {nd }}$ peak at $9.39 \%$ and the $1^{\text {st }}$ peak $(8.43 \%)$. The final decomposition of the EFB composite board is lower than of the UF resin at 389.26 to $380.83{ }^{\circ} \mathrm{C}$ indicating the presence of cellulose fibres (from EFB) significantly effecting on the thermal stability of the composite boards. This probably due to the disturbance in the original crystal lattice of the composite by the EFB composite boards (Singha \& Thakur, 2009). 


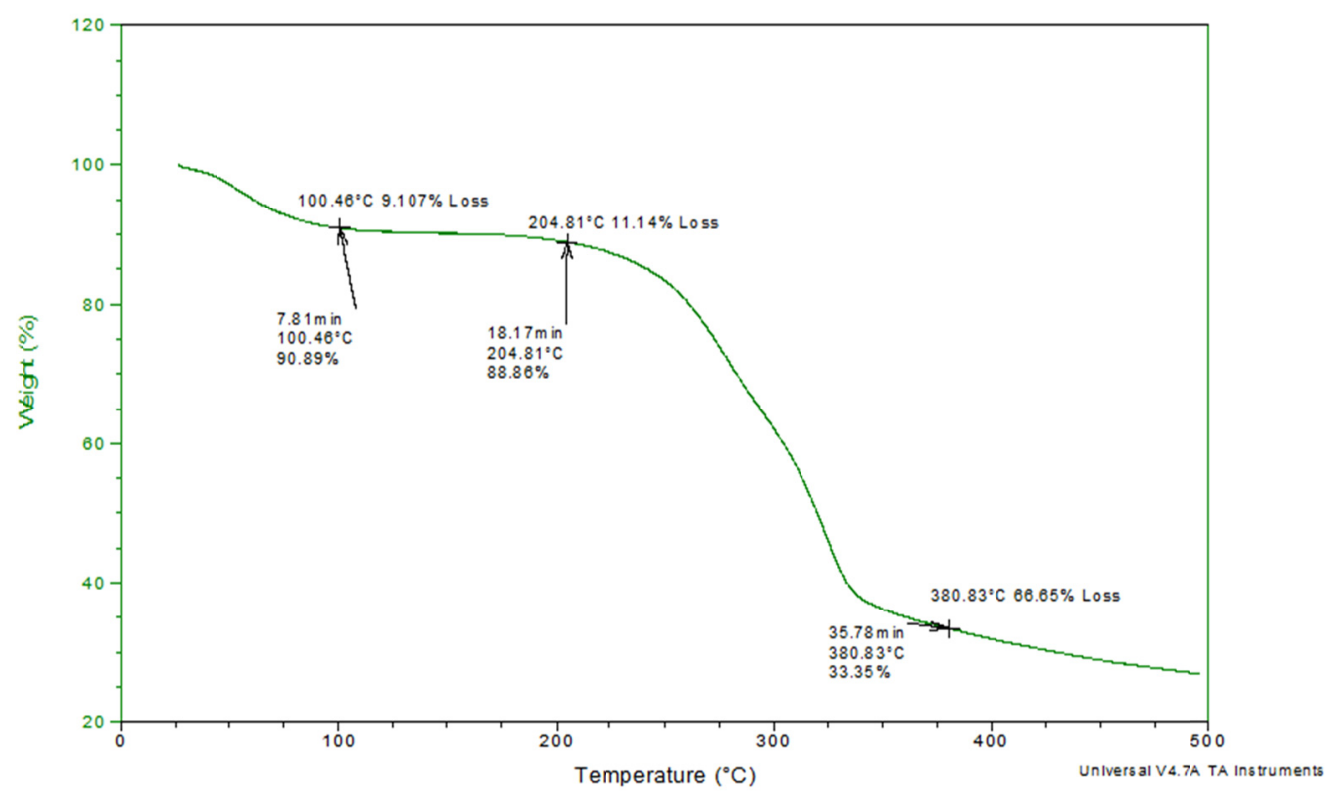

Figure 3. TGA properties of EFB composite boards

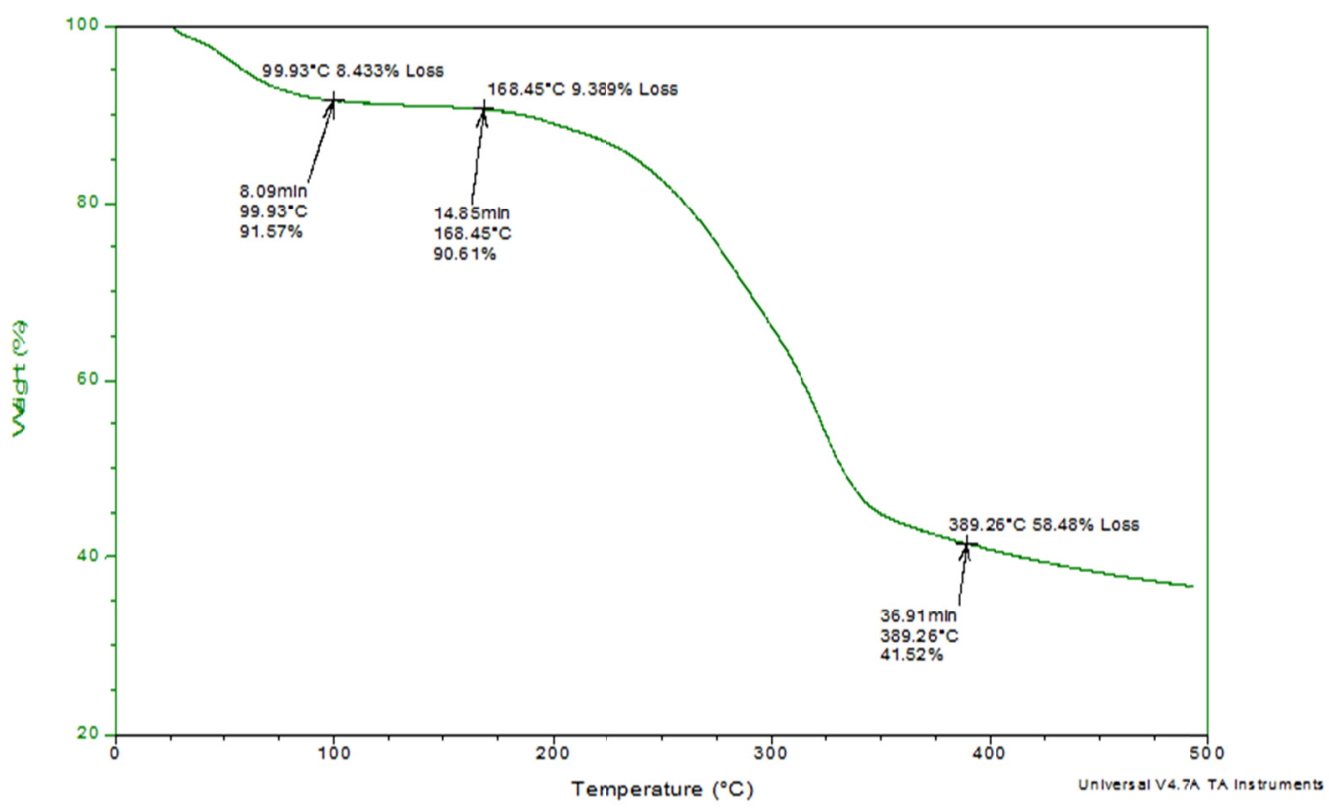

Figure 4. TGA properties of UF resin

The degradation of the EFB boards and UF resin started by the depolymerization of molecular structure and the dehydration (loss of water). The free formaldehyde in UF resin slowly released (Marashdeh et al., 2011; Zorba et al., 2008). The process continued by the cleave of linkages that occurred in the composite and UF resin. Carbon-hydrogen $(\mathrm{C}-\mathrm{H})$ bonds broken first, followed by carbon-oxygen (C-O) bonds, carbon-carbon (C-C) bonds, and hydrogen-oxygen $(\mathrm{O}-\mathrm{H})$ bonds. The energy needed to break those linkages were $414 \mathrm{~kJ} / \mathrm{mol}$ for $-\mathrm{C}-\mathrm{H}$ bond, $356 \mathrm{~kJ} / \mathrm{mol}$ for $-\mathrm{C}-\mathrm{O}$ bond and $347 \mathrm{~kJ} / \mathrm{mol}$ for $-\mathrm{C}-\mathrm{C}$ and last but not least the $\mathrm{O}-\mathrm{H}$ bond, $460 \mathrm{~kJ} / \mathrm{mol}$. This is the stage where cellulose, hemicellulose, and lignin began to decompose. The thermal degradation of polymer blocks of biomass occurred at the second peak. Hemicellulose and Lignin degraded earlier (Soom et al., 2006; Abdullah \& Bridgwater, 2006). This is due to their molecular structure that less rigid (amorphous than cellulose) compared to cellulose. The introduction of oxygen $\left(3^{\text {rd }}\right.$ peak), combustion occurred, and the final weight loss 
infers the amount of carbon in the composite. The carbon contents of the boards were $58.48 \%$ for UF resin and $66.65 \%$ for EFB composite boards (Table 5).

Table 5. TGA weight loss (\%) with temperature for EFB composite boards and UF resin

\begin{tabular}{lllll}
\hline & & $1^{\text {st }}$ peak & $2^{\text {nd }}$ peak & $3^{\text {rd }}$ peak \\
\hline EFB composite boards & Temperature $\left({ }^{\circ} \mathrm{C}\right)$ & 100.46 & 204.81 & 380.83 \\
& Weight loss $(\%)$ & 9.12 & 11.14 & 66.65 \\
\hline UF resin boards & Temperature $\left({ }^{\circ} \mathrm{C}\right)$ & 99.93 & 168.45 & 389.26 \\
& Weight loss $(\%)$ & 8.43 & 9.39 & 58.48 \\
\hline
\end{tabular}

\section{Conclusion}

The EFB eco-composite boards' properties met all requirements for commercial application in the timber industry. The boards' density and resin content applied influenced on the board's overall properties. The studies indicated an increase across the board physical and mechanical properties. The highest MOR and MOE value achieved in this study were $22.91 \mathrm{~N} / \mathrm{mm}^{2}$ and $2059.56 \mathrm{~N} / \mathrm{mm}^{2}$. The maximum value for internal bonding was $0.98 \mathrm{~N} / \mathrm{mm}^{2}$, meanwhile for edge and face screw withdrawal, $467.47 \mathrm{~N} / \mathrm{mm}^{2}$ and $512.37 \mathrm{~N} / \mathrm{mm}^{2}$.

The boards produced at density $700 \mathrm{~kg} / \mathrm{m}^{3}$ with $14 \%$ resin showed an excellent overall property with excellent dimensional stability. The boards are unlikely to swell with less porous structure when exposed to the wet environment. Boards produced at density $500 \mathrm{~kg} / \mathrm{m}^{3}$ with $10 \%$ resin possess low physical and strength properties.

This type of board, scanned under SEM, shows numerous voids structure that absorbs and traps moisture. Inter particle's bonding thus diminished as moisture interrupts, causing low board performance. The UF resin showed higher thermal stability compared to regular boards when analyzed under TGA. Thermogravimetric analysis conducted to study the thermal stability of the boards manufactured. The maximum rate of decomposition for the EFB composite board occurred at $380.83{ }^{\circ} \mathrm{C}$, where the temperature of the UF resin was $389.26{ }^{\circ} \mathrm{C}$, which explained that the UF resin by itself more stable than of the composite boards.

\section{References}

Abdullah, N., \& Bridgwater, A. V. (2006). Pyrolysis liquid derived from oil palm empty fruit bunches. Journal of Physical Science, 17(2), 117-129.

Ashori, A., \& Nourbakhsh, A. (2008). Effect of press cycle time and resin content on physical and mechanical properties of particleboard panels made from the under utilized low-quality raw materials. Industrial Crops and Products, 28(2), 225-230. https://doi.org/10.1016/j.indcrop.2008.02.015

British Standard BS 5669. (1989). Particleboard: Methods of sampling, conditioning, and test. British Standards Institution.

European Standard EN 310. (1993d). Wood-based panels: Determination of the modulus of elasticity in bending and of bending strength. European Committee for Standardisation, Brussels, Belgium.

European Standard EN 312-3. (1996). Particleboards-Specifications-Part 3: Requirements for boards for interior fitments (including furniture) for use in dry conditions. European Standardization Committee, Brussels.

European Standard EN 317. (1993c). Particleboard and Fibreboards; Determination of swelling in thickness after immersion in water. European Committee for Standardisation, Brussels, Belgium.

European Standard EN 322. (1993a). Wood-based panels: Determination of moisture content. European Committee for Standardisation, Brussels, Belgium.

European Standard EN 323. (1993b). Wood-based panels: Determination of density. European Committee for Standardization, Brussels, Belgium.

European Standard EN 325. (2012). Wood-based panels: Determination of dimensions of test pieces. European Committee for Standardization, Brussels- Belgium.

Garay, R. M., MacDonald, F., Acevedo, M. L., Calderón, B., \& Araya, J. E. (2009). Particleboard made with crop residues mixed with wood from Pinus radiata. BioResources, 4(4), 1396-1408. 
Guler, C., \& Büyüksarı, Ü. (2011). Effect of production parameters on the physical and mechanical properties of particleboards made from the peanut (Arachis hypogaea L.) hull. BioResources, 6(4), 5027-5036.

Khalid, I., Sulaiman, O., Hashim, R., Razak, W., Jumhuri, N., \& Rasat, M. S. M. (2015). Evaluation of layering effects and adhesive rates of laminated compressed composite panels made from oil palm (Elaeis guineensis) fronds. Materials \& Design, 68, 24-28.

Khalil, H. S. A., Alwani, M. S., \& Omar, A. K. M. (2007). Chemical composition, anatomy, lignin distribution, and cell wall structure of Malaysian plant waste fibres. BioResources, 1(2), 220-232. https://doi.org/ 10.1016/j.matdes.2014.12.007

Loh, Y. W., H'ng, P. S., Lee, S. H., Lum, W. C., \& Tan, C. K. (2010). Properties of particleboard produced from the admixture of rubberwood and mahang species. Asian Journal of Applied Sciences, 3(5), 310-316. https://doi.org/10.3923/ajaps.2010.310.316

Marashdeh, M. W., Hashim, R., Tajuddin, A. A., Bauk, S., \& Sulaiman, O. (2011). Effect of particle size on the characterization of binderless particleboard made from Rhizophora species. Mangrove wood for use as phantom material. BioResources, 6(4), 4028-4044.

Moslemi, A. A. (1974). Particleboard (Vol. 2). Southern Illinois University Press.

Papadopoulos, A. (2007). Property comparisons and bonding efficiency of UF and PMDI bonded particleboards as affected by key process variables. BioResources, 1(2), 201-208.

Paridah, M. T., Saifulazry, S. O. A., Jalaludin, H., Zaidon, A., \& Rahim, S. (2010). Mechanical and physical properties of particleboard made from 4-year-old rubberwood of RRIM 2000 series clones. Journal of Tropical Forest Sciences, 22(4), 440-447.

Rasat, M. S. M., Razak, W., Amal Najihah, M. N., Sitti Fatimah, M. R., Mahani, Y., \& Siti Aoshah, N. N. (2013e). Compressed oil palm fronds composite: A preliminary study on mechanical properties. International Journal of Science, 2(3), 31-41.

Rasat, M. S. M., Wahab, R., Kari, Z. A., Yunus, A. A. M., Moktar, J., \& Ramle, S. F. M. (2013b). Strength Properties of Bio-composite Lumbers from Lignocelluloses of Oil Palm Fronds Agricultural Residues. International Journal of Advanced Science, Engineering and Information Technology, 3(3), 09-19.

Rasat, M. S. M., Wahab, R., Shafie, A., Yunus, A. A. M., Yusoff, M., \& Kari, Z. A. (2013a). Effect of wood-fibre geometry size on mechanical properties of wood-fibre from Neolamarckia Cadamba species reinforced polypropylene composites. Journal of Tropical Resources and Sustainable Sciences, 1(1), 42-50.

Rasat, M. S. M., Wahab, R., Sulaiman, O., Moktar, J., Mohamed, A., Tabet, T. A., \& Khalid, I. (2011). Properties of composite boards from oil palm frond agricultural waste. BioResources, 6(4), 4389-4403.

Rasat, M. S. M., Wahab, R., Yunus, A. A. M., Moktar, J., Ramle, S. F. M., Kari, Z. A., \& Yusoff, M. (2013c). Physical and mechanical properties of Bio-Composite board from compressed Oil Palm Fronds. Advances in Natural and Applied Sciences, 7(5), 572-582.

Rasat, M. S. M., Wahab, R., Zulhisyam, A. K., Ag. Ahmad, M. Y., \& Sitti Fatimah, M. R. (2013d). Properties of bio-composite lumbers from lignocelluloses of oil palm fronds Agricultural residues. International Journal on Advanced Science Engineering Information Technology, 3(3), 9-19. https://doi.org/10.18517/ijaseit. 3.3.320

Rowell, R. M. (Ed.). (2012). Handbook of wood chemistry and wood composites. CRC Press.

Singha, A. S., \& Thakur, V. K. (2009). Study of mechanical properties of urea-formaldehyde thermosets reinforced by pine needle powder. BioResources, 4(1), 292-308.

Soom, R. M., Wan Hasamudin, W. H., Top, A. M., \& Hassan, K. (2006). Thermal properties of oil palm fibre, cellulose and its derivatives. Journal of Oil Palm Research, 18(December), 272-277.

Wahab, R., Abdus Salam, M., Sudin, M., Sulaiman, O., Mat Rasat, M. S., \& Samsi, H. S. (2013). Properties of engineered oil palm composite boards from 32 year-old tree stems. ARPN Journal of Agricultural and Biological Science, 8(7), 541-545.

Wahab, R., Khalid, I., Mohamed, M., Samsi, H. S., \& Mohd Fikri, A. (2016a). Physical, Mechanical and Thermal Properties of Bio-Composites Mixture of Gigantochloa Scortechinii and Themeda Arguens (L.) Hack at Different Ratios and Resin Contents. Research Journal of Pharmaceutical, Biological and Chemical Sciences, 7(4), 644-655. 
Wahab, R., Mohamed, M., Iqbal Ahmad, M., Samsi, H. S., Mustafa, M. T., \& Yusof, M. (2016c). Properties of Biocomposite Mixture of Oil Palm Frond and Kenaf Bast Fibers. Research Journal of Pharmaceutical, Biological and Chemical Sciences, 7(3), 986-994.

Wahab, R., Mustafa, M. T., Samsi, H. S., Mohamed, M., Mat Rasat, M. S., \& Yusof, M. (2016b). Physical, Mechanical and Morphological Studies on Bio-composite Mixture of Oil Palm Frond and Kenaf Bast Fibers. Journal of Plant Sciences, 11(1-3), 22-30. https://doi.org/10.3923/jps.2016.22.30

Wahab, R., Samsi, H. W., Mohamad, A., Sulaiman, O., \& Salim, R. (2008). Properties of Laminated veneer lumber from oil palm trunks. Journal of Plant Sciences, 3(4), 255-259. https://doi.org/10.3923/jps.2008. 255.259

Wai, H. Y., Tun, S., \& Naing, K. M. (2011). Particleboards Derived from Rattan Fibre Waste. Universities Research Journal, 4, 3.

Wei, Y. J., Silikas, N., Zhang, Z. T., \& Watts, D. C. (2011). Hygroscopic dimensional changes of self-adhering and new resin-matrix composites during water sorption/desorption cycles. Dental Materials, 27(3), 259-266. https://doi.org/10.1016/j.dental.2010.10.015

Wong, E. D., Zhang, M., Wang, Q., \& Kawai, S. (1999). Formation of the density profile and its effects on the properties of particleboard. Wood Science and Technology, 33(4), 327-340. https://doi.org/10.1007/ s002260050119

Yang, H. S., Kim, D. J., \& Kim, H. J. (2003). Rice straw-wood particle composite for sound absorbing wooden construction materials. Bioresource Technology, 86(2), 117-121. https://doi.org/10.1016/S0960-8524 (02)00163-3

Zheng, L., Pan, Z., Zhang, R., Jenkins, B. M., \& Blunk, S. (2005). Medium-density particleboard from saline Jose tall wheatgrass. Proceedings from 05 ASAE Annual International Meeting. Florida, USA. https://doi.org/10.13031/2013.19578

Zorba, T., Papadopoulou, E., Hatjiissaak, A., Paraskevopoulos, K. M., \& Chrissafis, K. (2008). Ureaformaldehyde resins characterized by thermal analysis and FTIR method. Journal of Thermal Analysis and Calorimetry, 92(1), 29-33. https://doi.org/10.1007/s10973-007-8731-2

\section{Copyrights}

Copyright for this article is retained by the author(s), with first publication rights granted to the journal.

This is an open-access article distributed under the terms and conditions of the Creative Commons Attribution license (http://creativecommons.org/licenses/by/4.0/). 